\title{
Secondary Predication and Default Case
}

\author{
Youngjun Jang \& Siyoun Kim \\ Chung-Ang University \\ yjang@cau.ac.kr \& domalady77@hotmail.com
}

\begin{abstract}
This paper compares secondary predication constructions (including small clause complements, resultatives, and/or depictives) in English and Korean and argues that these two typologically different languages employ different modes of satisfying the Case Filter (Chomsky 1981) with regard to the Case of the subjects of secondary predication constructions. More specifically, we argue that the subject of the secondary predicate in English is Accusative Case-marked by the higher governing verb, while that in Korean is Nominative Case-marked by default. Evidence for default Nominative Case will be provided from Korean and other languages.
\end{abstract}

\section{Introduction}

The purpose of this paper is to compare small clauses such as complement small clauses, resultatives, and/or depictives in English and Korean and argue that these two typologically different languages employ different modes of satisfying the Case Filter (Chomsky 1981) with regard to the Case checking/marking of the subjects of small clauses. More specifically, we argue that the subject of a small clause (or secondary predication) in English is Accusative Case-marked by the higher governing verb, while that in Korean is Nominative Case-marked by default.

In Section 2, we discuss the case properties of the subjects of small clauses in English, and show that the subjects of small clauses should be Accusative Case-marked either by raising to an appropriate Case position (Bowers 1993, 1997, 2001) or by changing the matrix governing verb into a "transitive" one (Kim and Maling 1997). In Section 3, we show that the subjects of small clauses in Korean are Accusative Case-marked or Nominative Casemarked according to the types of the matrix verbs. That is, if the matrix verb governing the subject of a small clause is transitive, then the subject is Accusative Case-marked. If the matrix verb governing the subject of a small clause is intransitive, on the other hand, then the subject is Nominative Case-marked, unlike in English. In this Section, we also argue that Korean employs default case strategy in order to satisfy the Case Filter with regard to the Case checking/marking of the subject of a small clause when there is no source of case assignment, while English employs various other strategies. In Section 4, we discuss the default case strategy from a more broad perspective. In this Section, we compare English and Korean with regard to satisfying the Case Filter. We argue that English allows of-insertion and/or a preposition-like complementizer for in order to mark Case on Caseless nouns, while Korean allows default Nominative Case for Caseless nouns. Section 5 concludes this paper.

\section{Case Filter and English Small Clauses}

It is generally assumed that the subject of the secondary predication has its Case 
assigned/checked by the matrix verb in English. Consider the following examples:
a. I consider [ $\underline{\text { him }}$ honest]
b. The gardener watered [the tulips flat]
c. The joggers ran [their Nikes threadbare]
d. The lion gnawed (*on) [the bone raw]
(complement small clause)
(transitive resultative)
(intransitive resultative)
(object depictive)

(1a) contains a complement small clause, (1b) and (1c) contain resultative small clauses, and (1d) contains a depictive small clause. Here we assume a verbless complement to be a small clause (see Williams 1980, Rothstein 1992, among others). Note in examples given in (1) that the subjects of these small clauses are all Case-marked by the governing verb of the matrix clause. That is, in (1a), him is Accusative Case-marked by the matrix verb consider. In (1b-c), the subjects the tulips and their Nikes are each assumed to be Case-marked by the matrix verbs watered and ran, respectively. In (1d), the bone is assumed to be Case-marked by the transitive-like gnawed (see Kim and Maling 1997, among many others).

Various mechanisms are proposed to account for the Case properties of these subjects of secondary predicates. For example, Stowell (1981) argues that the matrix verb "governs" into the subject of small clauses. Thus in (1a), the matrix verb consider "governs" into the bracketed category so that him is assigned/checked off its accusative Case.

In his extensive series of works on secondary predication, Bowers $(1993,1997,2001)$ assumes that the subjects of small clauses are posited in a Case position. In particular, he assumes that transitive resultatives are control constructions in which the subjects of the resultative predicates are in [Spec, VP] and that intransitive resultatives are raising constructions inwhich the subjects of the resultative predicates are raised from [Spec, PrP] to [Spec, VP]. Consider the two different structures given by Bowers (2001:327). According to him, the derivations of transitive resultatives would be as follows:

(2) transitive resultative

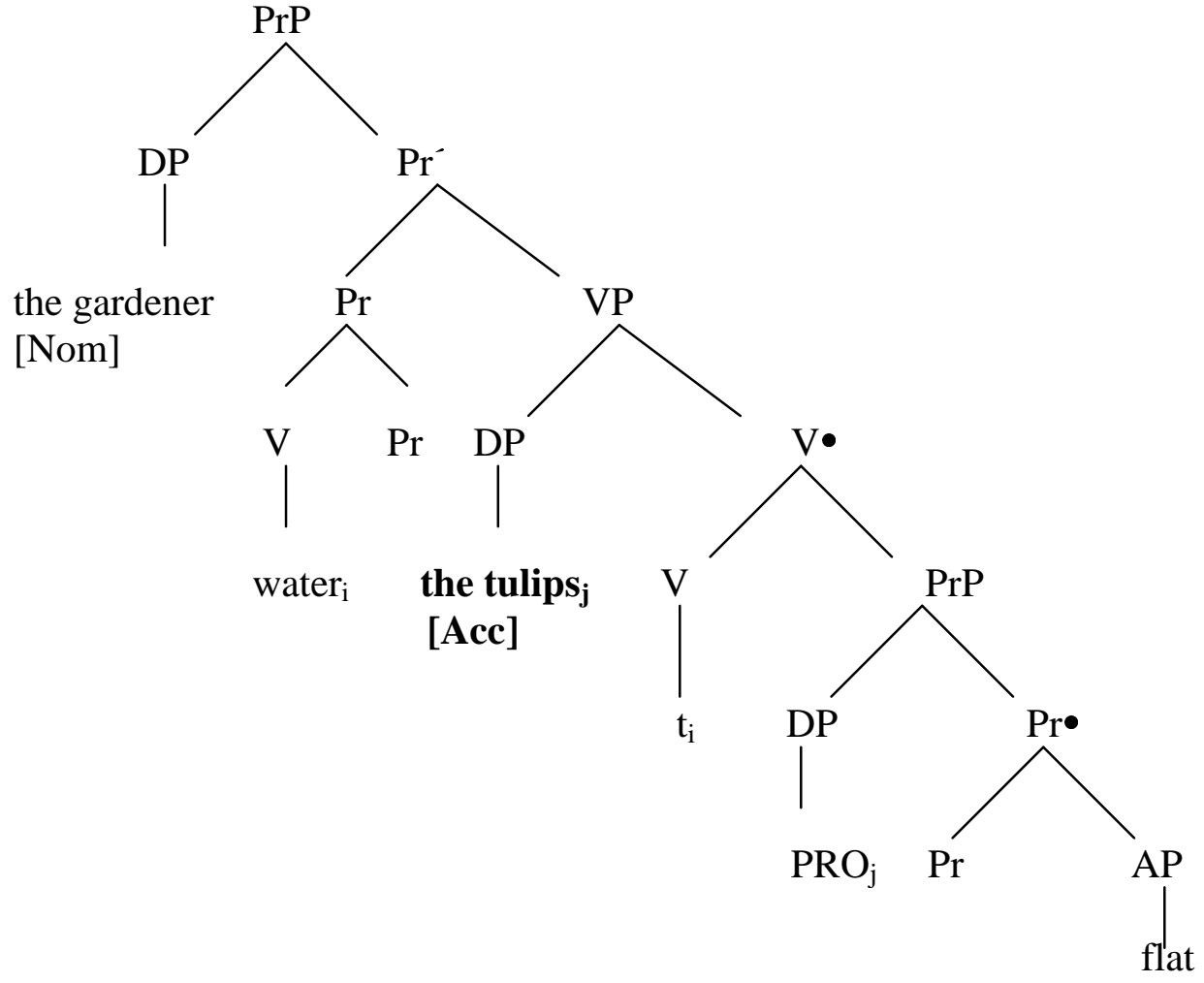


In the structure (2), the object of the matrix verb, namely the tulips, is in the [Spec, VP] and it controls the PRO subject of the secondary predicate, namely flat. Bowers (2001: 325) proposes the following structure for intransitive resultatives:

(3) Intransitive resultatives

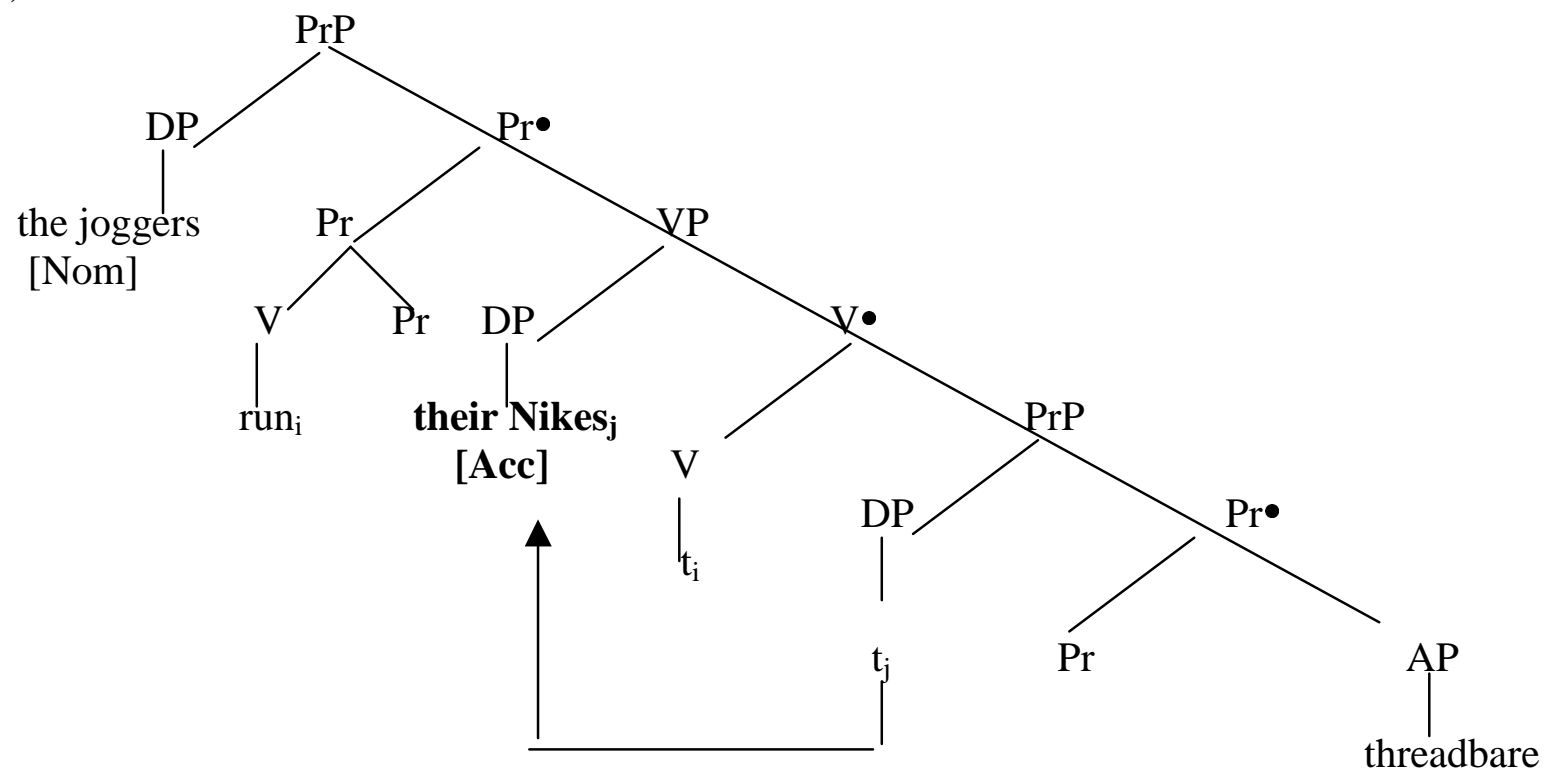

In the structure (3), the subject of the secondary predicate, namely their Nikes, is raised from [Spec, PRP] to [Spec, VP]. Bowers (1997: 45) argues that the strong [Acc] case-marked subject of the resultative PrP is forced to move overtly to [Spec, VP] to check case features. ${ }^{1}$ It is important for our purposes here to note that in both the transitive and intransitive structures, given in (2) and (3) respectively, the subject of the (so-called) predicate phrase PrP is in [Spec, VP] to which Accusative Case is assigned by the higher governing verb of the matrix clause. More examples of intransitive resultatives are provided below:

a. The kids laughed themselves into frenzy.

b. He sneezed his handkerchief completely soggy.

c. The tenors sang themselves hoarse.

In all of the examples above, the subjects of the secondary predicates are Accusative Casemarked by the matrix verbs, which are "intrinsically" intransitives.

On a different background, Kim and Maling (1997) argue that the matrix intransitive verbs of the intransitive resultative constructions undergo so-called "Resultative Formation," whereby the intransitive verbs change to transitive verbs so that they can assign/check Case. Consider their structures:

a. The lion gnawed (*on) [the bone raw]

b. The winemakers stomped $(*$ on) the grapes flat.

c. The professor lectured (*to) the class into a stupor.

\footnotetext{
${ }^{1}$ In general, Accusative Case in English is assumed to be weak, so that it can be checked off at LF. What Bowers intend to mean by "strong [Acc]" seems to be that the subject of the secondary predicate in English must be "overtly" Case-marked by matrix verb governing it.
} 
a. The lion gnawed $*($ on) the bone

b. The winemakers stomped $*($ on) the grapes.

c. The professor lectured $*$ (to) the class.

In the examples in (5), the matrix verbs are claimed to undergo so-called "Resultative Formation." Thus the prepositions are not allowed in these examples, while in the ordinary intransitive usage in (6) the prepositions should not be omitted. What is not clear about this kind of analysis is the nature of this transitive-formation. ${ }^{2}$ Converting intransitive verbs into transitive ones is not infrequent, but Kim and Maling (1997) do not discuss what exactly motivates the function-changing process in intransitive resultatives.

A process like "Resultative Formation" proposed in Kim and Maling (1997) seems to be needed, anyhow, to account for why the prepositions in the examples given in (5) are not allowed and, equally importantly, to explain why the "fake" reflexive objects are obligatory in the examples in (7) below:
a. Joggers often run *(themselves) sick
b. The kids laughed *(themselves) into a frenzy.
c. The tenors sang *(themselves) hoarse.

In the examples in (7), the reflexive objects should not be omitted. Otherwise, the Case (feature) of the matrix verbs may not be checked/saturated, after it is transformed into a transitive verb. ${ }^{3}$

In all of these analyses, one common feature is that Case Filter holds of the subjects of the secondary predicates in English and that Case Filter is satisfied by the "transitive-like" properties of the matrix verbs. In sum, the subjects of the secondary predicates in English are Case-marked and the case of these subjects is assigned/checked by the matrix verbs governing the subjects.

\section{Small Clauses in Korean}

In this section we are concerned with the two Case forms of the subjects of small clauses in Korean. In Section 3.1, it is shown that the subject of a small clause is Accusative Casemarked if the matrix verb is transitive, while that is Nominative Case-marked if the matrix verb is intransitive. In Section 3.2, we argue that the subject of a small clause in Korean is Nominative Case-marked by default if there is no case assigned (to the subject of the small

\footnotetext{
${ }^{2}$ It seems that in English semantic transitivity might be expressed in terms of syntactic transitivity. That is, resultative itself is a semantic transitive and this transitivity seems to be expressed by syntactic "transitivization" of the intransitive verbs. However, it does not necessarily hold cross-linguistically. See Section 4 of this paper for the case of Korean in which we argue that Korean intransitive resultatives do not under "Resultative Formation" in the sense of Kim and Maling (1997).

${ }^{3}$ Rothstein (1992:157) argues that case consideration cannot explain the obligatoriness of the pleonastic in examples like (i) below, since the assignment of accusative Case by a potentially Case-assigning verb is not obligatory:

(i) I consider [*(it) obvious that they had to leave]

We do not entirely agree with her, instead adopting the minimalist assumption that the Case feature of a functional head/lexical head must be checked off. Another possibility is that the so called Extended Projection Principle (EPP) is violated in (i) if the pleonastic it is omitted.
} 
clause) by the matrix verb.

\title{
3.1 Accusative and Nominative Subjects of Small Clauses
}

Bowers's $(1993,1997,2001)$ raising analysis of intransitive resultatives or Kim and Maling's (1997) "Resultative Formation" may not be extended over to Korean data. The subjects of the secondary predicates in Korean are invariably Accusative Case-marked if the matrix verbs are transitive verbs. This is illustrated in (8) below:

\author{
a. Robin-i [soy-lul/*ka ttukep-key] takkwu-ess-ta. (resultative) \\ Robin-Nom metal-Acc/*Nom hot-Comp heat-Past-Dec \\ 'Robin heated the metal hot.' \\ b. na-nun [Robin-ul/*-i cohci ahn-key] yeki-n-ta. (complement) \\ I-Top Robin-Acc/*Nom not good-Comp consider-Prs-Dec \\ 'I consider Robin not good.' \\ c. Robin-un umsik-ul/*-i cca-key mek-nun-ta (depictive) \\ Robin-Top food-Acc/*Nom salty-Comp eat-Prs-Ind \\ 'Robin eats food salty.'
}

In the examples in (8), the subjects of the secondary predicates are all Accusative Casemarked and not Nominative Case-marked. On the other hand, the subjects of the secondary predicate are invariably Nominative Case-marked, if the matrix verbs are intransitive. Consider the following (examples are taken from Kim and Maling 1997):
a. Robin-i [paykkop-i/*lul ppaci-key] wus-ess-ta (intransitive resultative) Robin-Nom belly-Nom/*Acc come.out-key laugh-Pst-Ind 'Robin laughed his belly out.'
b. Robin-un [nwun-i/*ul ppaci-key] (Mary-lul) kitari-ess-ta.
Robin-Top [eye-Nom/Acc come out-Comp] (Mary-Acc) wait-Past-Dec
'Robin waited (for Mary) (so long) that his eyes almost came out.'
c. Robin-un [kwutwu-ka/*lul talh-key] talli-ess-ta.
Robin-Top [shoes-Nom/*Acc threadbare-Comp run-Past-Dec

In examples in (9), the subjects are all Nominative Case-marked. This is strikingly different from the intransitive resultatives in English.

Suppose that Bowers's (1997) raising analysis or Kim and Maling's (1997) Resultative Formation analysis are correct in that the subject of the intransitive resultative predicate discussed so far must be in a Case position. That is, suppose that it is in [Spec, VP] in Bowers $(1997,2001)$ or in object position in Kim and Maling (1997). ${ }^{4}$ Suppose further that this analysis is intended to be applied cross-linguistically. Then it is incorrectly predicted that in (9) the subjects of the resultative predicates should be Accusative Case-marked and not Nominative Case-marked.

If the Case Filter (Chomsky 1981) is a universal condition and Korean is not an eception to its application, then we need to explain how the examples in (9) would be compatible with the Case Filter. In the next subsection we are concerned with this issue.

\footnotetext{
${ }^{4}$ Kim and Maling (1997) note in passing that the Nominative Case of the subjects of the Korean small clauses is assigned by the morpheme "-key". In this paper we assume, contra Kim and Maling (1997), that "-key" is simply a complementizer and does not assign Case. E.-K. Kang (2001) takes this morpheme to be a Predicate head, following Bowers (2001). For a similar approach to ours, see Sells (1998).
} 


\subsection{Default Nominative Case}

Given that the Case Filter is a universal condition, Korean data, in particular those in (9) seem to pose a potential problem. If the matrix verbs undergo "Resultative Formation" or if they are transitive verbs, then the subjects of the secondary predicates would be Accusative Casemarked. This is not the case, however.

A careful examination, however, reveals that it is only an apparent one. It is highly conceivable that languages may differ in allowing default Case strategy. Thus English and Korean may be parameterized with regard to the default Case strategy: English does not allow default Case strategy, while Korean does allow it. In the case of secondary predication, English employs "Raising to Case position" (see Bowers 1993, 1997, 2001) or "Resultative Formation"(see Kim and Maling 1997) to satisfy Case Filter. Korean does not employ these apparatuses since it allows default strategy. ${ }^{5}$ In the next section we provide evidence for the claim that we need to admit default Case strategy in Korean.

\section{Default Case in Korean and Other Languages}

In this section we provide arguments for our claim that Korean allows default Nominative Case when there is no source of any case for an argument NP. Supporting evidence includes Case phenomena in adjective constructions and in the infinitival constructions. We also provide supporting evidence from typologically unrelated languages such as Icelandic. Section 4.1 discusses the default Case strategy in Korean and Section 4.2 deals with default Case in other languages.

\subsection{Default Case in Korean}

In Korean, transitive verbs assign Accusative Case to its sister/complement, as shown in (10) below:

$$
\begin{array}{ll}
\text { Mary-ka } & \text { John-ul ttayri-ess-ta. } \\
\text { Mary-Nom } & \text { John-ACC heat-Past-Dec } \\
\text { 'Mary hit John.' } &
\end{array}
$$

Nominative Case is morphologically realized as $-k a$ and the accusative Case is realized as $l u l l^{6}$ There is a consensus on the assumption that structural Accusative Case in Korean is assigned by the verb to its object in transitive sentences, just like in English. Surprisingly enough, however, some objects are not Accusative Case-marked but Nominative Casemarked. This is illustrated in (11) below:

$$
\text { John-i Mary-ka coh-ta. (Adjective) }
$$

\footnotetext{
${ }^{5}$ Peter Svenonius (personal communication) suggests that an abstract and morphologically null preposition or postposition might assign Case in Korean secondary predication constructions. Since the distribution of Nominative Case in Korean is not uniform, positing an empty preposition/postposition may not be helpful.

${ }^{6}$ Nominative Case marker is $-i$ (as in John-i) if the NP ends with a consonant and Accusative Case marker is $l u l$ (as in Mary-lul) if the NP ends with a vowel. That is the choice between the Nominative markers $-k a$ and $-i$ and between the Accusative markers $-u l$ and $-l u l$ is phonologically conditioned.
} 
John-Nom Mary-Nom fond-Dec

'John is fond of Mary/John likes Mary.'

John-i chinkwu-ka iss-ta.

John-Nom friend-Nom be-Dec

'John has friends.'

In (11) the theme argument Mary is Nominative Case-marked, and in (12) the theme argument chinkwu is Nominative Case-marked. ${ }^{7}$ This is different from their English counterparts, given in the translations.

Y.-S. Kang (1986) first proposed that Nominative Case in Korean is a default Case. ${ }^{8}$ Kang's proposal for the Case marking system in Korean is as follows:

(13) Generalized Case Marking-ordered

a. An NP argument which is a sister of [-stative] V is assigned Accusative Case.

b. Nominative Case is assigned to all non-Case-marked NPs.

According to him, Accusative Case is assigned to the theme NP, say John in (10), since the predicate is [-stative], according to him. However, the theme NPs in (11-12), namely Mary and chinkwu, are marked as default Nominative Case, because the verb in these sentences is not [-stative].

M.-Y. Kang (1988:35) proposes a partial Default-Nominative Case Hypothesis. M.-Y. Kang claims that the Nominative Case-marking of the experiencer NP, namely John in (1112), as a consequence of structural Nominative Case assignment by INFL, whereas Nominative Case-marking on the theme NP, namely Mary and chinkwu, is viewed as a result of default Nominative Case assignment.

Saito $(1983,1985)$ also argues for the default Nominative Case strategy in Japanese. He argues that Nominative Case in Japanese is not assigned by INFL but assigned as a default Case. He notes that non-arguments may take Nominative Case marker in Japanese.
Yahari, [natu-ga [biiru-ga umai]]
after all summer-Nom beer-Nom tasty
'After all, it's during the summer that beer tastes good'

He points out that in (14) natu 'summer' is not an argument of the predicate umai 'tasty', and nevertheless takes the nominative marker - $g a$. This Japanese sentence can be translated into

\footnotetext{
${ }^{7}$ In some tradition of Korean grammar, the first Nominative marked NP is not considered as a subject. Rather it is considered as a topic experiencer and the second Nominative marked NP is considered as a real subject. Manki Lee (personal communication) points out that in Spanish the first NP is Dative Case marked and the second NP is a real subject. See the following example:

(i) me gusta Maria.

me.DAT like.3SG Mary.NOM

'I like Mary.'

In the example (i) the experiencer me is Dative and the subject Maria is Nominative. However, we assume that the theme NP is a syntactic object and the experiencer NP is a syntactic subject in Korean.

${ }^{8}$ Y.-S. Kang (1986) points out that there is no positive evidence that (AGR in) INFL assigns nominative Case in Korean, because Korean doesn't have AGR. He indicates that INFL in Korean doesn't have any independent properties as a head of $\mathrm{S}$, and concludes that the assumption that the nominative Case is assigned by INFL in Korean is unmotivated. We will not discuss in detail the Case assigning mechanism of Korean in this paper. Readers are referred to Y.-S. Kang (1986) and M.-Y. Kang (1988).
} 
its Korean equivalent: ${ }^{9}$

eccaysstun, [yelum-i [bie-ka choyko-ta]

after all summer-Nom beer-Nom tasty

'After all, it's during the summer that beer tastes good'

Thus, we are led to conclude that the non-argument yelum is assigned default Nominative Case, just like in Japanese.

Y. Kim (1991:135) provides several more arguments for default Nominative Case in Korean. According to her, a lexical NP can appear in the subject position of infinitival control constructions. Let us consider the following example, slightly changed from her sentence:
a. Inho-ka [s' [s PRO/caki-ka ka]-ko] sipheha-n-ta. ${ }^{10}$
Inho-Nom PRO/self-Nom go-comp hope-Pres-Dec
'Inho hopes PRO/self to go.'
b. Inho-ka [s' [s PRO/caki-ka ku kes-ul ha]-lyeko] ayssu-ess-ta. Inho-Nom PRO/self-Nom that thing-Acc do-Comp endeavor-Past-Dec 'Inho endeavored PRO/self to do it.'

Korean infinitival complement constructions like (16) have "obligatory control" property. That is, the following sentence is ungrammatical:
(16a)• *Inho-ka [s Yumi-ka ka-ko] sipheha-n-ta. Inho-Nom Yumi-Nom go-Comp hope-Pres-Dec
'*Inho hopes Yumi to go'

Returning to the control structure (16), the subject of the infinitival clause is PRO. As is well established, PRO must not be governed and hence is not Case-marked. ${ }^{11}$ That is, the subject position of the infinitival clause in (16) is not a Case position. Therefore, the nominative Case on the reflexive subject, namely caki, cannot be assigned any Case. simply because this position is not a Case position. Nevertheless, the subject caki of the infinitive complement occurs with the Nominative Case marker $-k a$. To account for the occurrence of the Nominative Case marker on this subject of the infinitival clause, Kim (1991) argues that we need to posit default Nominative Case marking.

There are other pieces of supporting evidence for the claim that Korean allows default Nominative Case for caseless NPs. Throughout the paper, we have assumed that English employs a special apparatus to satisfy the Case Filter. For example, "Resultative Formation" (Kim and Maling 1997) or Raising to [Spec, VP] (Bowers 1997) is needed to satisfy the Case Filter in secondary predication. On the other hand, the Case Filter is satisfied by default Case assigning strategy in Korean. Consider the following data:

\footnotetext{
${ }^{9}$ Carlson Schütze (1997) claims that $-k a$ in Korean is homophonous and that in this kind of example would be a focus/topic marker. Readers are referred to Schütze's work.

${ }^{10}$ The English glossary for sipheha-n-ta in the original sentence was "want". However, we changed it to "hope" to emphasize the control property of the given verb.

${ }^{11}$ We will not discuss the status of null Case of PRO. See Martin $(1999,2001)$ for null Case assignment on PRO.
} 


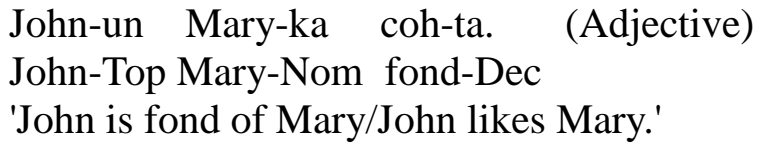

The sentence (17) is more readily translatable into "John is fond of Mary" rather than "John likes Mary." The adjective coh-ta 'fond' assigns theme role to its sister, but it does not assign Case to its sister. This is just like the English counterpart shown in (18):
a. John is fond *(of) Mary.
b. John is proud $*$ (of) his son.
c. John is aware *(of) the fact.
d. John is sure $*(o f)$ his appointment.

In the English examples in (18), it is clear that the adjectives assign theme role to their complements. It is also clear, however, that they do not assign Case to their complements. In order to satisfy the Case Filter, the preposition of is inserted in these particular cases. ${ }^{12}$

In contrast to this of-insertion strategy for satisfying the Case Filter, Korean seems to employ default Nominative Case. In other words, in cases like (17), where the adjective cohta 'fond' assigns theme role to its sister but it does not assign Case, as mentioned before, the Caseless NP, namely Mary, is assigned default Nominative Case. ${ }^{13}$

Another case of default Nominative Case in Korean is witnessed in infinitival constructions. Before discussing infinitival constructions, consider the following small clause construction:
John-un [sm Mary-lul ka-key] ha-ss-ta
John-Top Mary-Acc go-Comp do-Past-Dec
'John made Mary go.'

In (19) the matrix verb hayssta, which is a transitive (or causative) verb, assigns Accusative Case to the subject of the small clause, namely Mary. There seems to be no controversy on this point. The English counterpart of this example, given in the translation, suggests that Mary is Accusative Case-marked by the matrix verb made.

Now let us consider the infinitival clauses in Korean. It is important to note that the subject position of infinitival clauses is not a Case position. ${ }^{14}$

\footnotetext{
[IP ku-ka cinaka-tolok] John-up pilhyese-ss-ta

he-Nom pass by-Comp John-Top stand aside-Past-Dec

'John stood aside in order [for him to pass by].'
}

The embedded clause in (20) is an infinitival clause. Hence there is no tense or agreement marker in this infinitival clause, as shown in (21):

\footnotetext{
${ }^{12}$ In Chomsky (1986) it is argued that the preposition of is a realization of the inherent case borne by the complement of the theta-role assigning head. Admitting this, we still need to explain why the preposition of is inserted because other inherent case does not appear in some cases, as in English indirect-direct object order.

${ }^{13}$ We do not deny the existence of inherent Case. What we want to show is that even the inherent Case in English must be overtly marked/realized, while the inherent Case is automatically realized as Nominatie in Korean as a default Case.

${ }^{14}$ The subject position of control infinitival constructions is assumed to be assigned Null Case. See Martin (1999, 2001) and Chomsky (1995).
} 
* [IP ku-ka cinaka-ss-tolok] John-up pilhyese-ss-ta he-Nom pass by-Past-Comp John-Top stand aside-Past-Dec

'John stood aside in order [for him to pass by].'

As in English, the infinitival clause in Korean does not carry tense markers. Hence the ungrammaticality of (21). ${ }^{15}$ Given that in (20) the bracketed embedded clause is infinitival, there is no source of the Nominative Case on $k u$, the subject of the embedded infinitival clause. If the subject $k u$ is not Case-assigned, then the sentence would incorrectly be judged to be ungrammatical. This is, however, not the case. Thus we are led to admit that Korean allows default Nominative Case in this situation. Compare this sentence with its English counterpart, given in (22):

(22) [For him to pass by], John stood aside.

As is well known, the subject position of the infinitival clause in English is not a Case position (see footnote 10). Given the Case Filter, however, the subject him must be assigned any Case. Since English does not allow default Case strategy, him must be assigned Case by some appropriate Case-assigning head. The preposition-like complementizer for is thus employed only for Case theoretic reasons. Once again, an argument NP must be assigned Case in some way or other.

In sum, English does not allow default Case so that it employs of-insertion or prepositional complementizer for in cases where there is no source of Case. On the other hand, Korean allows default Nominative Case so that it does not need any special apparatus for satisfying the Case Filter.

\subsection{Default Case in Other Languages}

Icelandic also allows Nominative NPs to occur in the subject position of certain infinitival clauses. First of all, consider the examples in (23), cited from Thráinsson (1979: 299, 301): ${ }^{16}$
a. Maria skipaði [honum að vera goður/goðum/*goðan]
Mary ordered him(D) to be $\operatorname{good}(\mathrm{N} / \mathrm{D} / * \mathrm{~A})$
b. Maria bað [pa að vera goðir/goða/goðum]
Mary asked them(A) to be $\operatorname{good}(\mathrm{N} / \mathrm{A} / * \mathrm{D})$
a. Eg bað [hann að fara einn/einan/*einum pangað]
I asked $\operatorname{him}(\mathrm{A})$ to go alone $(\mathrm{N} / \mathrm{A} / * \mathrm{D})$ there
b. Eg skipaði [henni að fara ein/einni/eina pangað]
I ordered her(D) to go alone $(\mathrm{N} / \mathrm{D} / * \mathrm{~A})$ there
c. Mer virðist [Anna vera veik]
me-Dat seems Anna-Nom to-be sick

The examples in (23) are object-controlled infinitival constructions. In (23a), the Case agrees between predicate adjectives and their PRO subject. In (23b), subject-oriented adjuncts agree in case with their PRO subjects, which are controlled by the object of matrix verbs. The basic generalization about "object-controlled equi" sentences like $(23 \mathrm{a}, \mathrm{b})$ is that the predicate

\footnotetext{
${ }^{15}$ Kiyong Choi (personal communication) claims that there might not be default Case in Korean, by pointing out that even in (21) subject honorific agreement marker "-si" can be inserted. We do not incorporated such data because honorific agreement is quite often overgenerated.

${ }^{16} \mathrm{D}=$ Dative Case, $\mathrm{A}=$ Accusative Case, and $\mathrm{N}=$ Nominative Case
} 
adjectives and subject-oriented adjuncts agrees in case with the matrix controller (=the matrix object) or Nominative Case marked. What this means is that PRO is covertly Nominative Case marked. In certain raising constructions like (24c), a nominative lexical NP overtly shows up in the subject position of infinitival complements.

Andrew (1982: 470) proposes that Nominative Case in Icelandic should be considered an "unmarked case," so that there is no nominative case-marking rule, whereas objects will call for a restriction to the effect that their Case be ACC. His Case-Marking Rule does not introduce Nom, since, according to him, Nom is not a value of Case, but the absence of Case. The fact that both Icelandic and Korean allow Nominative Case marking in the subject position of certain infinitival clauses, unlike English, is consistent with the default nature of Nominative Case in both languages.

Y. Kim (1991) also cites McCloskey (1985) and McCloskey and Sells (1988). According to these works, in Irish and Classical Latin, and perhaps in Ancient Greek as well, lexical NPs show up in non-Case positions such as subject position of infinitival complements. These lexical NPs are, according to them, marked with default Accusative Case, as illustrated below:

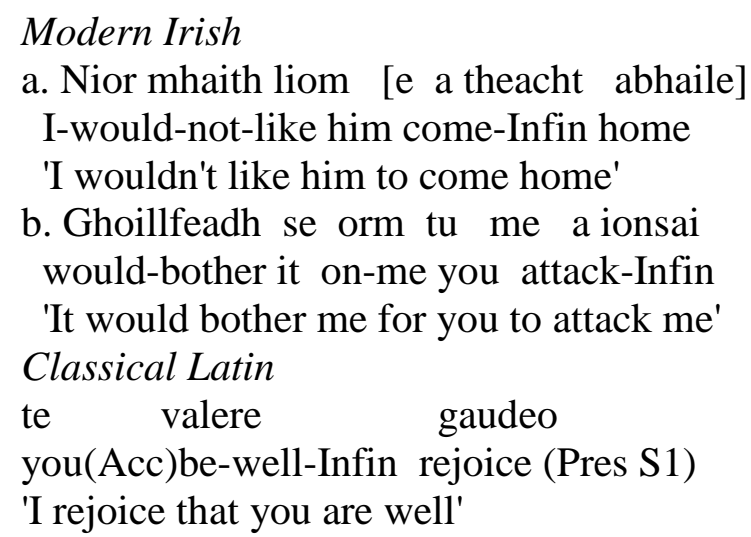

(McCloskey \& Sells 1988: 151)

(McCloskey 1985: 193)

From the discussion above, we would get the following conclusion: If a language has a default Case strategy, it allows a lexical NP in a non-Case position. On the other hand, if a language does not have a default Case strategy, a lexical NP cannot appear in a non-Case position, due to the Case Filter, or that NP should be assigned Case somehow.

\section{Concluding Remarks}

In this paper we argued that English and Korean differ from each other in satisfying the Case Filter. More specifically, we argued that the subject of a small clause in English is Accusative Case-marked by the matrix verb governing the subject, while that in Korean is assigned default Nominative Case.

In Section 2, we discussed the general case properties of the subjects of secondary predicates in English, and showed that the subjects of small clauses should be Accusative Case-marked either by raising to an appropriate Case position (Bowers 1997, 2001) or by changing the matrix verb into a "transitive" one (Kim and Maling 1997). By contrast, we showed that the subjects of small clauses in Korean are either Accusative Case-marked or Nominative Case-marked according to the types of the matrix verbs. That is, if the matrix verb governing the subject of a small clause is transitive, then the subject is Accusative Casemarked. If the matrix verb governing the subject of a small clause is intransitive, on the other 
hand, then the subject is Nominative Case-marked. In this section, we proposed that Korean employs default Case strategy in order to satisfy the Case Filter on the subject of a small clause when there is no source of case assignment. In Section 4, we discussed the default Case strategy from a more broad perspective. We argued that English allows of-insertion and/or a preposition-like complementizer for in order to mark Case on Caseless nouns, while Korean allows default Nominative Case for Caseless nouns. Default Case in other languages is also discussed in this section.

\section{References}

Baltin, Mark and Chris Collins (eds.). 2001. The handbook of contemporary syntactic theory. Cambridge, Mass.: Blackwell.

Bowers, John. 1993. The syntax of predication. Linguistic Inquiry 24: 591-656.

Bowers, John. 1997. A binary analysis of resultatives. In R. Blight and M. Moosally (eds.) Texas Linguistic Forum 38: 48-58.

Bowers, John. 2001. Predication. In M. Baltin and C. Collins (eds.) The Handbook of Contemporary Syntactic Theory. Cambridge, Mass.: Blackwell. Pp. 299-333.

Carrier, Jill and Janet Randall. 1992. The argument structure and syntactic structure of resultatives. Linguistic Inquiry 23: 173-234.

Chomsky, Noam. 1981. Lectures on Government and Binding. Dordrecht: Foris.

Chomsky, Noam. 1986. Knowledge of Language: Its Nature, Origin, and Use. New York: Praeger.

Chomsky, Noam. 1995. The Minimalist Program. Cambridge, Mass.: MIT Press.

Hornstein, Norbert. 2001. Move! A Minimalist Theory of Construal. Cambridge, Mass.: Blackwell.

Hornstein, Norbert and David Lightfoot. 1987. Predication and PRO. Language 63.

Jang, Youngjun. 1997. On the so-called adjunct predicates in Korean. In R. Blight and M. Moosally (eds.) Texas Linguistic Form 38: 149-160.

Jang, Youngjun and Si-youn Kim. 2001. Small clause complementizer. Paper presented at the 9th International Symposium on Korean Linguistics, Harvard University.

Kang, Young-Se. 1986. Korean syntax and universal grammar. Doctoral dissertation, Harvard University, Cambridge.

Kang, Myung-Yoon. 1988. Topics in Korean syntax. Doctoral dissertation, MIT, Cambridge.

Kang, Eun-Kyung. 2001. The -key constructions in Korean: Predicate Head or Complementizer. Paper presented at the 9th International Symposium on Korean Linguistics, Harvard University.

Kim, Jong-Bok. 1999. The syntax and semantics of English and Korean resultatives. NELS 31.

Kim, Soowon and Joan Maling. 1997. A crosslinguistic perspective on resultativeformation. In R. Blight and M. Moosally (eds.) Texas Linguistic Forum 38: 189-204.

Kim, Young-joo. 1991. Default nominative case in Korean. Studies in Generative Grammar 2: 113-148.

McClosky, James. 1985. Case, movement and raising in modern Irish. WCCFL 4.

McClosky, James and Peter Sells. 1988. Control and A-chains in modern Irish. Natural Language and Linguistic Theory 6.

Roberts, Ian. 1988. Predicative APs. Linguistic Inquiry 19: 703-710.

Rothstein, Susan. 1983. The syntactic form of predication. Doctoral dissertation, MIT, Cambridge.

Rothstein, Susan. 1992. Predication and the structure of clauses. Belgian Journal of 
Linguistics 7: 153-169.

Saito, Mamoru. 1983. Case and government in Japanese. In M. Barlow et al. (eds.) WCCFL.

Saito, Mamoru. 1985. Some asymmetries in Japanese and their theoretical implications. Doctoral dissertation, MIT, Cambridge.

Schütze, C. 1997 Infl in child and adult language: Agreement, case, and licensing. Ph.D. dissertation, MIT, Cambridge, Mass.

Sells, Peter. 1998. Structural relationships within complex predicates. Proceedings of the 1998 Biannual Meeting of the International Circle of Korean Linguistics, Hawaii.

Stowell, Tim. 1981. Origins of phrase structure. Doctoral dissertation, MIT, Cambridge.

Thráinsson, Hoskuldur. 1979. On complementation in Icelandic. Doctoral dissertation, Harvard University, Cambridge. New York: Garland Press.

Williams, Edwin. 1980. Predication. Linguistic Inquiry 11: 203-238.

Williams, Edwin. 1983. Against small clauses. Linguistic Inquiry 14: 287-308.

Williams, Edwin. 1985. PRO and subject of NP. Natural Language and Linguistic Theory 3: 297-315.

Zhang, Niina. 2001. The structures of depictive and resultative constructions in Chinese. ZAS papers in linguistics 22: 191-221.

Youngjun Jang \& Siyoun Kim

Department of English Language and Literature

Chung-Ang University

221 Hukseok-dong, Dongjak-ku

Seoul, Korea

Emails:

yjang@cau.ac.kr

http://cau.ac.kr/ yjang/

domalady77@ hotmail.com 